\title{
Matthew Beaumont, Andrew Hemingway, Esther Leslie, John Roberts (ed.): As Radical as Reality Itself. Essays on Marxism and Art for the $21^{\text {th }}$ Century
}

Bern: Peter Lang, 2007, 473 strani

Izhodišče antologije Tako radikalni kot realnost sama. Spisi o marksizmu in umetnosti za 21. stoletje lahko najdemo v konferenci »Marksizem in likovne umetnosti zdaj«, ki se je odvila aprila 2002 v organizaciji University College London. V tej knjigi sicer niso objavljeni prispevki s same konference, je pa zato to delo »testament intelektualni vznemirjenosti, ki jo je konferenca porodila« (str. 15). Večinoma britanski univerzitetni profesorji (in nekaj profesorjev iz tujine ter umetnikov) so si za nalogo zadali poiskati odgovor na vprašanje, kako v trenutni zgodovinski konjunkturi dediščino marksistične teorije in prakse »refunkcionirati«, ponovno zagnati, kako - v duhu političnega optimizma in intelektualnega pesimizma - poiskati nove smeri tako za marksizem kot za teorijo in kritiko materialne kulture (str. 16).

V tem smislu je pričujoča knjiga nadaljevanje antologije Marksizem in umetnostna zgodovina. Od Williama Morrisa do nove levice (ur. Andrew Hemingway, 2006), ki je namenjena predstavitvi predstavnikov starejše marksistične umetnostne zgodovine in teorije ( $\mathrm{ti}$ so $\mathrm{v}$ pregledih umetnostnozgodovinske historiografije večinoma zapostavljeni, bodisi obravnavani zelo površno bodisi gladko spregledani), in ki se zaključi s pregledom dogajanja v marksistični umetnostni zgodovini po letu 1968, s posebnim poudarkom na nemški umetnostnozgodovinski novi levici, ki v primerjavi $\mathrm{z}$ britansko in zlasti ameriško novo umetnostno zgodovino ostaja praktično neznana. Na tej točki pa se pričujoča antologija začne.

Predgovoru sledi šest tematskih sklopov. V uvodnih treh poglavjih (»Marksizem in umetnostna teorija: kratek pregled «, »Marksistična umetnostna zgodovina zdaj«, »Marksizem proti kulturnim študijem«) je predstavljena analiza oziroma diagnoza razmerja med marksizmom ter umetnostno zgodovino in teorijo od leta 1968 do danes.

Medtem ko je marksizem v povezavi s feminizmom okrog leta 1968 predstavljal ključni kritični impulz, iz katerega se je razvila nova umetnostna zgodovina, se je v akademskem 
svetu zadnjih desetletij marksizem moral umakniti postmodernizmu (z nazadovanjem marksizma neposredno povezano napredovanje postmodernizma, str. 13).

Marksizem je pripomogel $\mathrm{k}$ pretresanju in sesuvanju tradicionalne umetnostne zgodovine, bolj ali manj deklarativno antiteoretske in empiricistične, zamejene na slogovne in ikonografske analize, katerih poslednji namen je $\mathrm{v}$ resnici estetsko občudovanje del, ki jih je $\mathrm{v}$ svojem skoraj že božanskem umu spočel in nato mojstrsko udejanjil genialni Umetnik. Historična kritika naj bi tako umetniška dela detranscendentalizirala, pokazala naj bi na njihovo uporabnost v razmerju do družbene oblasti in postavila pod vprašaj status umetnika kot edinega ali vsaj primarnega vira njihovega pomena (str. 31). In na tem temelju bi stala t. i. nova umetnostna zgodovina.

Vendar, opozarja Andrew Hemingway, marksistična umetnostna zgodovina in nova umetnostna zgodovina še zdaleč nista sopomenki in, kakor so se stvari iztekle, med njima v resnici ni nujne povezave (str. 29). Po eni strani je socialna zgodovina umetnosti postala »mlačna ortodoksija«: upoštevanje družbeno-političnih oziroma zgodovinskih okoliščin pri interpretiranju umetniških del in pojavov je dandanes vseprisotno, po drugi strani pa se zdi, da je marksizem uspešno poražen. Na teoretski ravni kot ključni razlog za ta poraz Hemingway navaja razpad prvotne povezanosti marksizma s feminizmom, ki se je zgodil v poznih 1970-ih letih, ter nesposobnost marksizma, da bi ponudil primerna orodja za analizo psihoseksualnega, zaradi česar se je bilo treba zateči k psihoanalitični teoriji (str. 32). K zatonu marksizma so pripomogle tudi družbene okoliščine: politični zasuk v desno v zahodnih demokracijah v 1980ih letih, delavsko gibanje je oslabelo, povojni socialdemokratski konsenz se je znašel pod udarom neoliberalizma, zgodovinski komunizem je propadel. Za pomembno se je izkazala tudi mikrosociološka situacija: finančno vedno bolj podhranjen univerzitetni univerzum je vedno bolj prežet s tekmovalnim etosom. Bitka za vidnost (in preživetje) $\mathrm{v}$ akademskem svetu je porodila lakoto po novostih in lahkotnem avantgardizmu, ki pogosto le pozira kot politika. Večinoma umetnostni zgodovinarji niso prav nič antikapitalistično nastrojeni, zato nimajo razloga, da bi se pajdašili z marksizmom, in tisti, ki jih ideja radikalnosti privlači, se raje oprimejo modne politike subjektivnosti, ki je le novi obraz liberalizma in zagotovo ni antisistemska (str. 33). Tako je, kakor pripominja Matthew Beaumont, analitične kategorije historičnega materializma nadomestil nov niz operativnih terminov: namesto o zgodovini govorimo o spominu, namesto blagovnega fetišizma nas fascinira fetišizem, namesto o izkoriščanju govorimo o zatiranju, namesto produkcije nas zanima konsumpcija, namesto da bi prisegali na dialektiko, prisegamo na razliko, namesto o dejavnikih razpravljamo o identiteti (str. 14).

Pravi problem marksistične umetnostne zgodovine je v tem, pravi Hemingway, da o vrednosti ter omejitvah marksistične tradicije $\mathrm{v}$ umetnostni zgodovini še ni bilo 
nobene resne teoretske razprave. Nasprotno, marksistično razmišljanje o umetnosti je pogosto napačno predstavljeno ali celo karikirano (str. 33). Umetnostna zgodovina tudi ne premore močnih marksističnih teoretskih glasov, ki bi govorili s tako avtoriteto kakor Raymond Williams ali Terry Eagleton na področju književnosti. Edini umetnostni zgodovinar, ki se je pripravljen izpostaviti s temeljitejšim in daljnosežnejšim marksističnim teoretiziranjem, je O. K. Werckmeister, vendar mu Hemingway očita, da izziv, ki so ga marksizmu nastavile druge teoretske pozicije, apriorno zavrača (namesto da bi poskušal odgovoriti nanj, prisega na čistost marksistične misli, str. 34). Marksistična umetnostna zgodovina se tako zdi teoretsko nerazvita (str. 35) in pričujoče delo naj bi spodbudilo k prepotrebni razpravi in prepotrebnemu teoretskemu razvoju.

V nadaljevanju se prispevkiv sklopu »Država in revolucija «s pomočjo marksističnih in poststrukturalističnih konceptov lotevajo razlaganja določenih umetniških pojavov: z Marxovim in Derridajevim razumevanjem razmerja med dejavnikom in strukturo se poveže revolucionarno slikarstvo Jacques-Louisa Davida (»Senca dejavnika: Derrida, Marx, David«), mehiški muralizem je analiziran s pomočjo Foucaultovega oblastnega aparata (»Reprezentacija, institucionalizacija in država: marksistični in poststrukturalistični pristop k mehiškemu muralizmu in popularnemu«), Milenijski park v Chicagu pa s pomočjo Marxovega koncepta politične ekonomije (»Marksizem in zidano okolje v 21. stoletju: Milenijski park v Chicagu in vprašanje zasebnega in javnega prostora«). Kakor je običajno v novoumetnostnozgodovinskih (večinoma poststrukturalističnih) ukvarjanjih $\mathrm{z}$ umetnostjo, razlagi izbranega teoretskega koncepta sledi njegova aplikacija na izbran umetniški pojav.

Prispevki sklopa »Komunistična in postkomunistična estetika« se posvečajo analizi umetniških pojavov iz komunističnih družb: grafičnega oblikovanja pri ruskih konstruktivistih (»Socialistični objekt ruskega konstruktivizma kot model estetske vrednosti«), motiva dela v vzhodnonemški umetnosti (»Delo kot umetniški motiv: teoretski in slikovni vzori iz Nemške demokratične republike: zgodovinska skica«) ter ikonoklastičnega zrušenja Moskovskega kina v Varšavi po padcu komunizma (»Rušim Moskvo! Dejanja simbolnega uničevanja v postkomunističnem obdobju«).

V sklopu »Situacionistična misel in cilji avantgarde« trije prispevki (»So bili situacionisti poslednja avantgarda?«, „Delati nikoli! Situacionisti in politika negacije«, »Konsumacija spektakla: Wattsov upor in novi proletariat«) izkazujejo še vedno močno fascinacijo s situacionisti kot "poslednjo avantgardo" in se jih lotevajo s tega ali onega zornega kota, zadnji prispevek pa je namenjen predstavitvi Tafurijeve teorije o modernistični arhitekturi, kakor jo je razvil v knjigi Arhitektura in utopija. 
Prispevki zadnjih dveh sklopov, "Subjektivnost in blagovna forma« ter "Politika in problem sodobne prakse" (»Modularnost in estetika samopoblagovljenja«, »Procesualni performans: kritične pripombe $\mathrm{k}$ Adornovi avtonomni umetnini«, »Teorija vrednosti pri Marxu in Adornu« ter "Globalizacija, kulturna razlika in alternativa današnji krizi umetnosti«, "Pod nered ( ). Po »avtorju kot producentu««, »Temna snov. Aktivistična umetnost in protijavna sfera«), pa so bolj esejistično zastavljeni, bolj raznoliki in vsebinsko manj oprijemljivi.

Po začetni ekspoziciji revnega mesta marksizma v umetnostni zgodovini prispevki sami, v svoji značilno novoumetnostnozgodovinski razdrobljenosti, prispevajo bolj malo uporabne vednosti za grajenje obče marksistične umetnostne zgodovine (izjema bi lahko bil članek Mary C. Koffey o mehiških muralistih). Gre bolj za to, da knjiga s svojim samim obstojem, čisto na fizičen način torej, opozori, da si potrebnih vprašanj nismo še niti zares zastavili, kaj šele odgovorili nanje s temeljitim premislekom. Žal pa je to, že zgolj opomin sam po sebi, da marksizem (v umetnostni zgodovini) še ni mrtev, že precejšen dosežek. 